\title{
Kesenian Tradisional Sebagai Sarana Strategi Kebudayaan di Tengah Determinasi Teknologi Komunikasi
}

\author{
Oleh Agus Maladi Irianto \\ Fakultas Ilmu Budaya, Universitas Diponegoro \\ Jalan Prof. Soedarto Tembalang Semarang, Indonesia \\ E-mail: ami.fibundip@gmail.com
}

\begin{abstract}
Traditional art in this paper is seen as cultural identity for its supported community, that has a specific role socially and ritually. The supported community, in addition, believes that this traditional art is not only acted as an entertainment, but also a facilitator for their hopes and prays. Despite some changes have influenced the differences of style and variation in the performing art, however, the changes themselves are the manifestation of adaptive strategy had from the supported community to preserve and conservetraditional art. Determination of communications technology or the exposure of communications technology present in the midst of society and influence the worldview and human behavior in everyday life.
\end{abstract}

Keywords: art, traditional, determinism, culture, globalization

\section{Intisari}

Kesenian tradisional dalam tulisan berikut dilihat sebagai identitas kultural masyarakat pendukungnya yang berfungsi secara sosial dan ritual. Kesenian tradisional ini juga dipercaya masyarakat pendukungmya tidak sekadar sebagai hiburan yang menciptakan kegembiraan, namun ia juga menjadi media yang mampu memfasilitasi doa dan harapan mereka. Kendatipun penyajian kesenian tradisional saat ini mengalami perubahan berbagai gaya dan variasi, namun secara fungsional hal itu merupakan bentuk strategi adaptif masyarakat pendukung dalam mempertahankan dan melestarikan kesenian tradisional. Determinasi teknologi komunikasi atau terpaan teknologi komunikasi hadir di tengah-tengah masyarakat dan memengaruhi cara pandang dan perilaku manusia dalam kehidupan sehari-hari, termasuk di dalamnya pada kesenian tradisional mereka.

Kata kunci: Kesenian, tradisional, deteminasi, kebudayaan, globalisasi

\section{Pendahuluan}

Perkembangan teknologi komunikasi dan globalisasi ekonomi pada dasarnya membawa konsekuensi terhadap nilai dan gaya hidup suatu masyarakat. Meminjam istilah Smith (2001:214-232), perkembangan sosial saat ini, pada dasarnya telah melampaui pemikiran modernitas (yang ditandai dengan munculnya industri barang dan jasa) menuju pemikiran pascamodernitas yang cenderung lebih diorganisasikan oleh seputar, perkembangan teknologi informasi, konsumsi budaya dan permainan media massa. harus termajinalisasi oleh kehadiran globalisasi ekonomi yang sudah menjadi 
keniscayaan. Globalisasi ekonomi memicu setiap produk-produk budaya berkontestasi secara terbuka dan kreatif (Irianto, 2016b: 213-236, Panjaitan dan Sundawa, D., 2016: 64-72), dan Surahman, 2016:31-41).

Dampak dari globalisasi ekonomi juga terdistribusi ke sejumlah relasi kehidupan masyarakat, tak terkecuali terhadap eksistensi kesenian tradisional yang selama ini dianggap sebagai identitas kultural bagi masyarakat pendukungnya (Irianto, Suharyo, dan Hermintoyo, 2015: 19-25 dan Pereira, 2017)). Akibat tuntutan dunia global itulah, mengubah cara pandang masyarakat pendukung kesenian tradisional terhadap keberadaan kesenian tradisional. Ia tidak hanya disikapi sebagai identitas kultural yang mengakomodasi tuntutan ritual masyarakat pendukungnya semata, kesenian tradisional saat ini juga dituntut menjadi komoditi hiburan yang memuat unsur komersial (Irianto, Suharyo, dan Wiranto, 2010). Eksistensi kesenian tradisional di era globalisasi ekonomi saat ini, berada pada benturan antara nilai tradisional yang mengabdi pada harmoni, keselarasan, dan mistis dengan nilai-nilai kontemporer yang cenderung diorganisasi oleh perkembangan teknologi informasi, konsumsi budaya, dan permainan media massa (Irianto, 2016a: 2355-3820).

Eksistensi kesenian tradisional saat ini, harus termajinalisasi karena dianggap kurang memenuhi tuntutan standar industri pariwisata yang merupakan anak kandung dunia global (Irianto, 2016b: 213-236). Kesenian tradisional ada dan berkembang tentu saja berkaitan dengan makna, fungsi, dan kebudayaan yang melatarbekangi masyarakat pendukungnya. Masyarakat yang berlatar belakang petani misalnya, di sela-sela memenuhi kebutuhan utamanya mereka akan senantiasa mencari peluang untuk mengungkapkan ekspresinya melalui kesenian (Irianto, 2005: 21-35). Salah satu ciri masyarakat petani adalah tidak ingin hidup sendiri, apalagi dalam rangka menanggulangi ketergantungan terhadap musim. Mereka lebih merasa nyaman dalam kehidupan komunal daripada individual. Atas tuntutan menciptakan kebersamaan itulah, seni pertunjukan tradisional diselenggarakan secara kolektif masyarakat petani sematamata lebih mengutamakan ketenteraman dan kedamaian di antara mereka (Irianto dan Thohir, 2004). Bertolak dari sikap mengutamakan kedamaian dan ketentraman itulah, sejumlah aturan, norma, serta bentuk ekspresi kesenian tradisional diwariskan ke generasi berikut melalui tradisi-tradisi untuk menopang dan mempertahankan kolektivitas sosial (Irianto, 2016a: 2355-3820). 
Seiring dengan tuntutan dunia global, pewarisan tradisi-tradisi untuk menopang dan mempertahankan kolektivitas sosial mengalami hambatan yang cukup signifikan. Salah satu penghambat proses pewarisan tradisi di era pascamodernitas adalah memudarkan identitas kultural yang selama ini melekat pada diri masyarakat pendukung (Pereira, 2017: 125-152). Persoalan yang mengemuka dalam perkembangan karya seni di era pascamodernitas ini, lebih mengacu pada fenomena pertentangan antara isu-isu identitas kultural dengan otonomi karya seni (Himawan, 2014: 74-88). Determinasi teknologi komunikasi dan globalisasi media terhadap kesenian tradisional, telah mengubah cara pandang masyarakat sehari-hari yang selama ini mengembangkan tradisi untuk mempertahankan kolektivitas sosialnya (Surahman, 2016:31-41 dan Radzuan, I.S.M., Fukami, N., \& Ahmad, Y., 2014: 130-146). Di sinilah diperlukan strategi kreatif dan inovatif melestarikan nilai-nilai terkandung dari kesenian tradisional yang telah menjadi bagian kearifan lokal suatu suku bangsa. Pelestarian nilai-nilai kearifan lokal merupakan salah cara memperkuat identitas kultural suatu masyarakat (Panjaitan dan Sundawa, D., 2016: 64-72). Pertanyaan yang muncul adalah, bagaimana revitalisasi kesenian tradisional di tengah determinasi teknologi komunikasi dapat dijadikan strategi kebudayaan Indonesia?

\section{Metode Penelitian}

Tujuan penelitian ini, pertama memberikan wawasan baru tentang strategi dan pengembangan kesenian tradisional di tengah determinasi teknologi informasi. Kedua, menemukan model-model alternatif melindungi kesenian tradisional sebagai identitas kultural masyarakat pendukung, tetapi tetap sinergis dengan tuntutan globalisasi. Untuk mendukung tujuan kegiatan tersebut, maka dilakukan penelitian lapangan. Penelitian lapangan pada dasarnya sebagai validasi tentang persepsi dan respons, pandangan, serta strategi masyarakat pendukung melestarikan kesenian tradisional. Penelitian lapangan dilakukan di 4 (empat) kota Provinsi Jawa Tengah yang mewakili masyarakat petani (masyarakat pedalaman) dan masyarakat nelayan (masyarakat pesisir). Keempat kota tersebut terdiri dari 2 (dua) kota mewakili masyarakat pesisiran dan 2 (dua) kota mewakili masyarakat pedalaman. Pemilihan dua tipe masyarakat tersebut diharapkan mewakili pengetahuan lokal menyikapi kesenian tradisional sebagai identitas kultural mereka. Identitas kultural masyarakat pesisiran diwakili kesenian tradisional 
Pekalongan dan Jepara, sedangkan identitas kultural masyarakat pedalaman diwakili oleh kesenian tradisional Blora dan Banyumas.

Penelitian dengan pendekatan kualitatif ini yang berusaha memahami secara mendalam dan holistik terhadap sejumlah fenomena yang dipelajari dan bukan untuk menguji hipotesis yang diajukan berdasarkan model rumus-rumus statistik. Untuk mendapatkan data tersebut, langkah penelitian yang dilakukan adalah dengan cara observasi, wawancara mendalam, dan focus group discussion (FGD). Observasi dilakukan untuk mendeskripsikan gambaran riil di lapangan tentang kondisi kesenian tradisional dan objek wisata di lokasi kajian. Sedangkan kegiatan wawancara dan FGD dilakukan terhadap sejumlah informan untuk mendapatkan gambaran secara komprehensif tentang persepsi dan respons, padangan, sikap, harapan mereka terhadap keberadaan kesenian tradisional. Para informan tersebut di antaranya adalah tokoh masyarakat, tokoh agama, serta tokoh-tokoh strategis lainnya.

Hasil observasi, wawancara mendalam, dan FGD tersebut dianalisis ke dalam model-model kategori, pembandingan, dan kekontrasan dan kemudian menginterpretasikannya (Creswell, 1994: 153-154). Interpretasi data dilakukan secara sistemik yaitu memahami suatu fakta/data dengan mempertimbangkan faktor-faktor lain yang terkait di dalamnya. Sedang untuk memahami faktor-faktor yang saling terkait dari data yang diperoleh tersebut, dikembangkan berdasarkan pada kerangka pemikiran masyarakat yang dipelajari bukan didasarkan pada ukuran peneliti (Denzin \& Lincoln, eds., 1994: 43-45).

\section{Hasil dan Pembahasan}

Bertolak dari tuntutan dunia global, pewarisan tradisi-tradisi untuk menopang dan mempertahankan kolektivitas sosial mengalami hambatan yang cukup signifikan. Salah satu penghambat proses pewarisan tradisi di era pascamodernitas adalah memudarkan identitas kultural yang selama ini melekat pada diri masyarakat pendukung. Atas pertimbangan itulah, pada subbab ini akan diuraikan dua hal, yakni (1) identitas kultural yang selama ini menandai dinamika sosial masyarakat Indonesia dan (2) strategi kebudayaan Indonesia melalui kesenian tradisional dalam bentuk multimedia.

\section{Identitas Kultural Masyarakat Indonesia}


Meskipun masyarakat Indonesia terdiri dari bermacam etnik dan multikultural, tetapi secara tradisional latar belakang kebudayaan negeri ini lebih ditentukan tipologi kebudayaan masyarakat petani dan nelayan, agraris dan maritim, pesisiran dan pedalaman (Irianto, 2009:31-64). Tipologi masyarakat petani misalnya, adalah masyarakat yang terdiri dari orang-orang yang tinggal di pedesaan dan bermatapencaharian sebagai petani, dan mereka sejak lama terikat dalam suatu ikatan tradisi dan perasaan. Dengan terus memegang tradisi dan perasaan itulah, maka mereka menganggap bahwa dunia pertanian dan dirinya merupakan bagian yang saling berhubungan erat. Mereka bekerja di sawah bukan semata-mata untuk mencari keuntungan, tetapi lebih cenderung untuk mencukupi keperluan keluarganya yang sederhana atau hak untuk hidup pada paras subsistens (Irianto, 2016a:2355-3820).

Harus diakui, pengetahuan masyarakat petani pada dasarnya lebih bersifat sosial daripada ekonomi. Temuan Irianto dan Thohir (2004) menyebutkan bahwa nilai dan sikap masyarakat petani cenderung lebih mengutamakan ketenteraman dan kedamaian tanpa harus memaksakan keinginan lebih daripada yang mereka miliki selama ini. Inilah yang lazim disebut sebagai nilai dan sikap yang mempertahankan tradisi kecil dan moral lokal (misalnya, mereka masih berpegang pada azas pembagian pendapatan sama rata meskipun mereka harus hidup pada paras subsistens. Mereka lebih merasa nyaman dalam kehidupan komunal daripada individual. Mereka cenderung bersepakat dengan sesama petani lainnya, ihwal kapan lahan-lahan diolah, jenis bibit dipilih, dan masa panenan dilakukan dalam waktu hampir bersamaan. Pelajaran seperti ini menjadikan mereka sangat konvensional, dalam arti tidak menyukai perubahan. Setiap perubahan dimaknai sebagai bermain spekulasi. Berani bermain spekulasi berarti masuk ke dalam ranah ketidakpastian.

Sementara tipologi masyarakat nelayan, adalah lebih bertolak dari hal-hal yang melingkupi pekerjaan yang berhubungan dengan laut dan sumber daya yang ada di dalamnya. Laut sebagai tempat kerja dalam satu segi, dan daratan sebagai tempat tinggal, menggambarkan perbedaan-perbedaan sifat antarkeduanya. Karena itu, nelayan pada dasarnya memiliki tingkat adaptasi kepada lingkungan secara baik. Adaptasi di laut berkaitan dengan sifat-sifat laut, gelombang laut, udara (arus angin), lingkungan di mana ikan-ikan berkumpul dan bergerak, serta beradaptasi kepada sarana mobilitas (perahu, atau kapal, dan peralatan-peralatan yang digunakan) serta beradaptasi kepada antarsesama nelayan untuk melakukan aktivitas penangkapan ikan, pembagian peran 
dan tugas, serta pembagian hasil. Keseluruhan hal itu tidak mudah untuk dikerjakan oleh karena itu, sebetulnya kaum nelayan pada dasarnya adalah kelompok orang yang memiliki keberanian menghadapi resiko. Pengalaman hidup mencari ikan di lautan, menjadikan nelayan berani berspekulasi.

Kedua tipologi kebudayaan tradisional masyarakat itulah yang telah menentukan identitas kultural bangsa Indonesia, namun seiring dengan perkembangan pengetahuan global justru menjadi sulit untuk dipertahankan. Dari sinilah strategi kebudayaan sangat dibutuhkan untuk menentukan arah kehidupan bangsa Indonesia, sebab ia memuat dua fungsi pokok, yaitu sebagai pedoman memperkuat identitas kesatuan bangsa Indonesia yang majemuk Indonesia dan pedoman dalam pengembangan pengetahuan masyarakat Indonesia yang terus menerus berubah.

\section{Strategi Kebudayaan Indonesia Melalui Kesenian Tradisional Berbasis Multimedia}

Harus disadari bahwa kajian terhadap kesenian tradisional sudah banyak dilakukan sejumlah peneliti. Keberadaan kesenian tradisional seringkali disikapi sebagai ekspresi dan identitas kultural sekaligus berbasis kearifan dan keunikan lokal suatu masyarakat (Irianto, 2015 dan Murphy, K.M., 2017:3). Selain itu, kesenian tradisional ada dan berkembang dibakukan melalui tradisi-tradisi suatu masyarakat, serta untuk menopang dan mempertahankan kolektivitas sosial (Irianto, 2005: 45). Kesenian tradisional, bagi masyarakat pendukung dipandang sebagai salah satu media yang mampu melegitimasi keberadaan dan mempertahankan identitas mereka (Radzuan, I. S. M., Fukami, N., \& Ahmad, Y., 2014:130-146). Selain itu, kesenian tradisional dianggap sebagai salah satu aktivitas yang dipercaya dapat menyatukan antara unsur olah tubuh dengan magis. Kesenian tradisional, oleh masyarakat pendukung dianggap sebagai penghubung nilainilai ritual dengan konsep-konsep kesederhanaan dan kegotongroyongan di antara mereka (Nugraheni, 2014: 71-75).

Seiring dengan perkembangan peradaban suatu suku bangsa, kesenian tradisional dituntut menjadi komoditi hiburan yang memuat unsur komersial (Irianto, 2016b: 213-236). Pada era globalisasi ekonomi, memicu setiap produk-produk budaya berkontestasi secara terbuka dan kreatif. Dampak dari globalisasi ekonomi juga terdistribusi ke sejumlah relasi kehidupan masyarakat, tak terkecuali terhadap eksistensi kesenian tradisi yang selama ini dianggap sebagai identitas kultural bagi masyarakat 
pendukungnya (Irianto, Suharyo, dan Hermintoyo, 2015). Globalisasi ekonomi dalam konteks masyarakat Indonesia saat ini, tumbuh beriringan dengan perkembangan konsumsi budaya. Pertumbuhan itu membentuk transformasi kapitalisme konsumsi yang ditandai dengan menjamurnya pusat perbelanjaan bergaya seperti shopping mall, industri waktu luang, industri mode atau fashion, industri kecantikan, industri kuliner, industri nasihat, industri gosip, kawasan huni mewah, apartemen, iklan barang-barang mewah, makanan instan (fast food), serta reproduksi dan transfer gaya hidup melalui iklan dan media (Irianto, 2009:31-64, Irianto, 2014: 5-15, dan Irianto, 2017)

Sebagai contoh, kehadiran industri penyiaran televisi di Indonesia saat ini telah membentuk pengetahuan tentang suatu realitas yang serba cepat, sekaligus memuat strategi komunikasi agar mampu memelihara atau mengubah sikap atau pendapat sasaran demi kepentingan sumber pembuat strategi (Irianto, 2013). Sehingga, dapat dikatakan bahwa televisi ini cenderung mengajak audience-nya agar patuh kepada pihak yang menguasai modal komunikasi, baik dalam konteks politik maupun ekonomi. Intervensi lain yang mempengaruhi identitas kultural suatu masyarakat di era pascamodernitas ini, adalah munculnya industri pariwisata (Irianto, 2016b:213-236). Masyarakat yang selama ini diperkirakan mampu mempertahankan budaya homogen pun, akibat industri pariwisata sangat rentan berubah. Riset yang dilakukan Himawan, Sabana, dan Kusmara (2016: 96-101) memberi contoh masyarakat Bali yang dilatarbelakangi budaya homogen Hindu Bali, industri pariwisata telah mengubah ekspresi seni di antara mereka.

Dengan masuknya arus globalisasi ke Indonesia, kesenian tradisional menghadapi tantangan nilai baru yang melahirkan perangkat-perangkat praktis. Lahirnya perangkat-perangkat praktis yang berbasis informasi, komunikasi, dan teknologi melahirkan industrialisasi yang selalu mengarah pada orientasi pasar. Perangkat-perangkat tersebut, memproduksi dan mereproduksi ekspresi kebudayaan sebanyak-banyaknya di era globalisasi menjadi suatu keniscayaan (Kuswarsantyo, 2013). Untuk itulah, diperlukan strategi untuk bisa merevitalisasi kesenian tradisi agar tetap bertahan sekaligus mengimbangi tuntutan globalisasi. Kesenian tradisi yang selama ini menjadi ekspresi masyarakat pendukung untuk menciptakan keserasian antara manusia dan lingkungannya, harus menyesuaikan diri dengan kebutuhan pasar yang sejalan dengan tuntutan globalisasi (Coates, 2017: 7-21 dan Pereira, 2017: 125$152)$. 
Perkembangan dan tuntutan globalisasi yang ditandai dengan kemajuan teknologi, idealnya harus disikapi sebagai moment yang baik untuk memberi ruang kreatif dan inovatif bagi revitalisasi kesenian tradisional. Untuk itulah, gerakan pelestarian kesenian tradisional dalam bentuk multimedia ini dilakukan. Dengan adanya gerakan pelestarian kesenian tradisional dalam bentuk multimedia memberi kontribusi terhadap strategi kebudayaan Indonesia. Strategi kebudayaan pada saat ini sangat dibutuhkan bagi bangsa Indonesia seiring dengan berkembangnya paham intoleransi karena lunturnya nasionalisme bangsa, sekaligus sebagai soft diplomacy bagi NKRI ke dunia internasional. Strategi kebudayaan adalah rencana besar kehidupan suatu bangsa dan masa depannya. Ia merupakan grand design yang patut disikapkan sebagai cetak biru suatu bangsa. Strategi kebudayaan mengandung pengertian bagaimana cara atau usaha merencanakan dapat diwujudkan atau juga dikatakan sebagai sebuah gerakan revitalisasi kebudayaan dari berbagai produk budaya.

Diskursus tentang strategi kebudayaan Indonesia juga mengemuka pada acara "Simposium Budaya Kebangsaan: Strategi Kebudayaan Menuju Indonesia Hebat" yang diselenggarakan oleh Pusat Studi Kebudayaan UGM, 5 Juni 2017 lalu. Dalam acara tersebut, menyimpulkan bahwa strategi kebudayaan sangat dibutuhkan bagi bangsa Indonesia pada saat ini. Strategi kebudayaan diharapkan mampu sebagai penangkal berkembangnya paham intoleransi karena lunturnya nasionalisme bangsa. Pengalaman yang dilakukan negara Korea Selatan, melakukan strategi kebudayaan dengan mengembangkan budaya pop telah menunjukkan pengaruh signifikan di kalangan generasi muda dari berbagai belahan dunia. Misalnya, Gangnam Style yang semula merupakan kesenian tradisional direvitalisasi dalam bentuk multimedia menjadi salah satu soft diplomacy dan sangat familiar ke seluruh penjuru dunia. Gerakan soft diplomacy Korea Selatan merupakan bentuk strategi kebudayaan dengan berbasis multimedia sejalan dengan tuntutan era globalisasi (Irianto, 2014: 5-15).

Bertolak dari sejumlah argumentasi tersebut, dapat dikatakan bahwa keberadaan kesenian tradisional pada era pascamodernitas ini dapat disenergiskan dengan tuntutan globalisasi, sepanjang telah ditentukan arah kehidupan bangsa Indonesia dalam bentuk strategi kebudayaan. Kesenian tradisional yang selama ini lebih cenderung berbentuk seni pertunjukan dan penciptanya selalu anonim misalnya, akan menemukan sejumlah kendala untuk dilestasrikan. Hal itu terjadi, karena wujud dan bentuk seni pertunjukan tradisional akan hilang bersamaan dengan selesainya pertunjukan tersebut. Hal itu 
berbeda dengan seni rupa dan seni sastra, bentuk karya seninya masih bisa dinikmati orang lain, meskipun karya tersebut sudah selesai diciptakan oleh seniman atau sastrawan masih tetap bisa menikmatinya, bahkan menyimpan dalam waktu yang tidak terbatas. Seni pertunjukan, pada dasarnya memerlukan "dimensi ruang" dan "dimensi waktu" untuk sampai diapresiasi penontonnya, sementara seni rupa dan seni sastra hanya memerlukan "dimensi ruang" (Irianto, 2016a: 2355-3820). Bertolak dari "dimensi waktu" dan "dimensi ruang" serta anonimnya sang pencipta, menyebabkan pertunjukan kesenian tradisional menjadi seni sesaat dan tidak awet. Untuk itulah, dibutuhkan adanya revitalisasi kesenian tradisional dalam bentuk multimedia. Revitalisasi dalam bentuk multimedia pada dasarnya menempatkan posisi kesenian tradisional tetap terlindungi dan dapat diwariskan dari generasi ke generasi berikut tanpa harus termarjinalisasi oleh tuntutan ekonomi global.

\section{Kesimpulan}

1. Kesenian tradisional dalam tulisan berikut dilihat sebagai identitas kultural masyarakat pendukungnya, yang berfungsi secara sosial dan ritual. Kesenian tradisional ini juga dipercaya masyarakat pendukung tidak sekadar sebagai hiburan yang menciptakan kegembiraan, namun ia juga menjadi media yang mampu memfasilitasi doa dan harapan mereka.

2. Masyarakat Indonesia secara tradisional latar belakang kebudayaan negeri ini lebih ditentukan tipologi kebudayaan masyarakat petani dan nelayan, agraris dan maritim, pesisiran dan pedalaman. Kesenian tradisional dari dua tipologi masyarakat itulah yang selama menandai identitas kultural masyarakat.

3. Seiring dengan tuntutan dunia global, pewarisan tradisi-tradisi (termasuk kesenian tradisional) untuk menopang dan mempertahankan kolektivitas sosial mengalami hambatan yang cukup signifikan. Salah satu penghambat proses pewarisan tradisi di era pascamodernitas adalah memudarkan identitas kultural yang selama ini melekat pada diri masyarakat pendukung.

4. Tuntutan globalisasi idealnya harus disikapi sebagai momen yang baik untuk memberi ruang kreatif dan inovatif bagi revitalisasi kesenian tradisional. Diharapkan ia menjadi salah satu gerakan strategi kebudayaan dan soft diplomacy bangsa Indonesia ke tingkat internasional. 


\section{Daftar Pustaka}

Coates, Emily (2017). "The Poetics of Physics in Dance". PAJ: A Journal of Performance and Art. 39 (2): 7-21

Denzin, Norman K. \& Yvonna S. Lincoln, eds. (1994). Handbook of Qualitative Research. USA: SAGE Publication.

Himawan, Willy. (2014). "Historis dan Identitas Pariwisata Bali dalam Seni Lukis". Journal of Urban Society's Art . 1(1): 74-88

Irianto, Agus Maladi. (2005). Tayub, Antara Ritualitas dan Sensualitas: Erotika Petani Jawa Memuja Dewi. Semarang: Lengkongcilik Press

Irianto, Agus Maladi. (2009). "Media dan Multikulturalisme" dalam Multikulturalisme Yogyakarta dan Identitas Keindonesiaan, (Editor: Sri Rahayu Budiarti dan Muslimin A.R. Effendy). Jakarta: Departemen Kebudayaan dan Pariwisata Republik Indonesia.Hal. 31-64.

Irianto, Agus Maladi. (2010). Membuat Film Dokumenter. Semarang: Dinas Kebudayaan dan Pariwisata Jateng.

Irianto, Agus Maladi. (2013). "Mass Media Reality In Indonesia: The Local Wisdom That Were Marginalized By The TV Broadcast". Presented in The International Seminar on Education as Media of Socialization and Enculturation of Local Culture. Held by the Graduate School of Education and Human Developoment, Nagoya University, Juni $25^{\text {th }}$.

Irianto, Agus Maladi. (2014). Media dan Kekuasaan: Antropologi Membaca Dunia Kontemporer. Semarang: Gigih Pustaka Mandiri.

Irianto, Agus Maladi. (2016a). "The Development of Traditional Performance as an Adaptive Strategy Used by Javanese Farmers". Jurnal Harmonia 16 (1) (2016): 2355-3820.

Irianto, Agus Maladi. (2016b). "Komodifikasi Budaya di Era Ekonomi Global Terhadap Kearifan Lokal: Studi Kasus Eksistensi Industri Pariwisata dan Kesenian Tradisional di Jawa Tengah”. Dimuat di Jurnal Theologia. 27 (1): 212-236.

Irianto, Agus Maladi. (2017). "Media Dan Kebudayaan: Tantangan Ilmu Antropologi Membaca Dunia Kontemporer". Pidato Pengukuhan Guru Besar di Universitas Diponegoro, tanggal 23 Maret 2017.

Irianto dan Thohir, M. (2004). "Ekosistem Dieng dan Kebijakan Daerah Kabupaten Wonosobo" (laporan penelitian). Semarang: Puslit Sosbud LPPM Undip.

Irianto, Agus Maladi, Suharyo, dan Wiranto. (2010). "Model-Model Pengembangan Atraksi Kesenian Tradisional Wonosobo, Sebagai Strategi Pemahaman 
Wawasan Wisata Masyarakat Lokal". (Laporan penelitian). Semarang: LPPM Undip.

Irianto, Agus Maladi, Suharyo, dan Hermintoyo (2015). "Mengemas Kesenian Tradisional Dalam Bentuk Industri Kreatif, Studi Kasus Kesenian Tradisional" (laporan penelitian). Semarang: LPPM Undip.

Kuswarsantyo. (2013). "Seni Tradisional: Bentuk, Fungsi, dan Perkembangannya (1986-2013)”. Disertasi. Yogyakarta: Fakultas Bahasa dan Seni, UNY.

Murphy, K. M. (2017). “A Quiet Harvest: Linkage Between Ritual, Seed Selection and the Historical Use of the Finger-Bladed Knife as a Traditional Plant Breeding Tool in Ifugao, Philippines". Journal of Ethnobiology and Ethnomedicine, 13(1): 3 .

Nugraheni, Marina Catur. (2014). "Analisis Sosiologi Budaya dalam Kesenian Tradisional Tradisional Tri Tunggal Muda Budaya, Dusun Gejiwan, Desa Krinjing, Kecamatan Kajoran, Kabupaten Magelang”. Jurnal Program Studi Pendidikan Bahasa dan Sastra Jawa Universitas Muhammadiyah Purworejo. 4(5), 71-75

Panjaitan, Lopiana Margaretha dan Dadang Sundawa. (2016). "Pelestarian Nilai-Nilai Civic Culture dalam Memperkuat Identitas Budaya Masyarakat: Makna Simbolik Ulos dalam Pelaksanaan Perkawinan Masyarakat Batak Toba di Sitorang”. Journal of Urban Society's Art.. 3 (2): 64-72.

Pereira, C. (2017). "Religious Dances and Tourism: Perceptions Of The 'Tribal' as the Repository of the Traditional in Goa, India". Etnográfica. Revista do Centro em Rede de Investigação em Antropologia, 21(1)), 125-152

Radzuan, I. S. M., Fukami, N., \& Ahmad, Y. (2014). "Cultural Heritage, Incentives System and the Sustainable Community: Lessons from Ogimachi Village, Japan”. Geografia: Malaysian Journal of Society and Space, 10(1), 130-146.

Surahman, Sigit. (2016). "Determinisme Teknologi Komunikasi dan Globalisasi Media Terhadap Seni Budaya Indonesia". Jurnal Rekam, 12 (1): 31-41. 